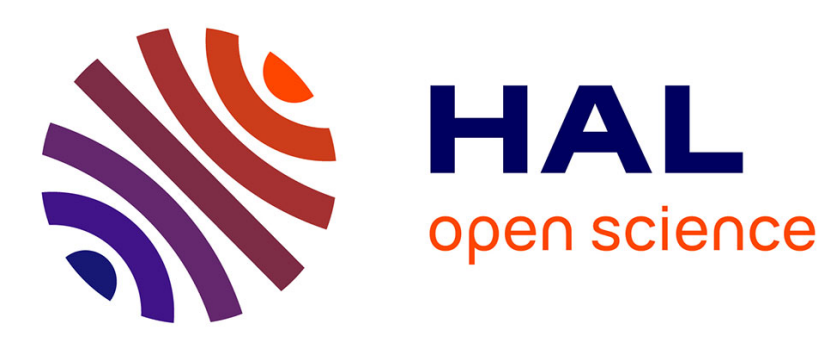

\title{
Affordances and Effects of Promoting eParticipation Through Social Media
}

\author{
Fathul Wahid, Øystein Sæbø
}

\section{To cite this version:}

Fathul Wahid, Øystein Sæbø. Affordances and Effects of Promoting eParticipation Through Social Media. 7th International Conference on Electronic Participation (ePart), Aug 2015, Thessaloniki, Greece. pp.3-14, 10.1007/978-3-319-22500-5_1 . hal-01587628

\section{HAL Id: hal-01587628 \\ https://hal.inria.fr/hal-01587628}

Submitted on 14 Sep 2017

HAL is a multi-disciplinary open access archive for the deposit and dissemination of scientific research documents, whether they are published or not. The documents may come from teaching and research institutions in France or abroad, or from public or private research centers.
L'archive ouverte pluridisciplinaire HAL, est destinée au dépôt et à la diffusion de documents scientifiques de niveau recherche, publiés ou non, émanant des établissements d'enseignement et de recherche français ou étrangers, des laboratoires publics ou privés. 


\title{
Affordances and effects of promoting eParticipation through social media
}

\author{
Fathul Wahid ${ }^{1,2}$, and Øystein $\mathrm{Sæb}^{1}$ \\ ${ }^{1}$ Department of Information Systems, University of Agder, Kristiansand, Norway \\ ${ }^{2}$ Department of Informatics, Universitas Islam Indonesia, Yogyakara, Indonesia \\ ffathul.wahid, oystein.sabo\}@uia.no
}

\begin{abstract}
A growing body of literature highlights the adoption of social media for eParticipation, focusing on the identification of processes and structures through which ICT supports the relationship between citizens, governments and public bodies. There is a need to better understand the role of technology in such initiatives. This paper addresses this issue by introducing the concept of affordance. We used a case study approach to investigate an Indonesian eParticipation projects from Bandung, identifying affordance perceptions, enabling and inhibiting factors, actualized affordances and affordances effects. From the use of social media we identify nine actualized affordances and their effects, and we discuss the relationship between them. The case introduces findings from a developing country, a context that has largely been ignored within eParticipation research. Our findings provide lessons learned for practitioners on how to organize their eParticipation projects, as well as for researchers identifying future research avenues to strengthen our understanding of the role of ICT by introducing the concept of affordances.
\end{abstract}

Keywords. eParticipation, Affordances, Indonesia, Social Media

\section{$1 \quad$ Introduction}

Information and communication technologies (ICTs) are increasingly being adopted to involve citizens in decision-making processes [1], intending to recapture citizens' declining interest in politics. eParticipation, research focuses on the identification of the processes and structures through which ICT supports the relationship between citizens, governments and public bodies [2,3]. The introduction of social media may change the political landscape [4] and enable new opportunities for communication, consultation and dialogue between public bodies and citizens [1]. ICTs may also be used in political debates and decision-making processes to complement or contrast traditional means of communication and to coordinate participation in political processes [5].

The majority of eParticipation research focus on projects from the traditional context of ICT-related studies in the developed world, focusing on how traditional egovernment stakeholders, such as political parties, citizens and public administrations [4], incorporate ICT-based services in an interplay with traditional communication 
channels [6]. The implementation of ICT is often done through the incremental development of existing services, based on the idea of continuously developing better and more mature eParticipation services. There is a need for further investigation into the "black box" of eParticipation initiatives - that is, an exploration of the internal processes and concurrent consequences of the use of ICT [7] and of the challenges and opportunities for both institutional and non-institutional stakeholders.

In this landscape, the use of ICT to encourage direct participation in political processes in the city Bandung in Indonesia represents an exceptional case through which to generate new knowledge within this area. First, this case represents novel initiatives from the research context of developing countries. Cultural, political, economic and social contextual issues differentiate our case from the majority of reported research within the area. Second, the strategy in Bandung represents a disruptive approach [8], where the use of social media is introduced both to communicate with citizens and other external stakeholders and to coordinate internal processes, despite the lack of widespread inclusion of ICT in most governmental services. Hence, their strategy is differentiated from the traditional incremental and stepwise approach otherwise reported in the field. Third, by introducing the concept of affordances in the analysis of our cases, our study contribute to an increased understanding of the role that technology plays in relation to goal-oriented actors.

In this paper, we analyse this the Bandung case with the aim of investigating and reflecting on the use ICT (particularly emphasising social media) to promote eParticipation within developing countries. Topics of interest include how and why social media are used (or not), the impact of so doing and the enabling and inhibiting factors influencing this use. We introduce the concept of affordances to explore these issues. The concept has become popular within the area of IS to explore the adoption of technology within organizational arrangements resulting from the combination of work practices and features offered by the innovative use of IT [9].

\section{Affordances: Theoretical Premises}

Originating from the work of ecological physiologists $[10,11]$, the concept of affordances focuses on interactions between actors (those being involved) with the environment (the surroundings of the actors), including the properties of actors and the environment [10]. The concept of affordance has become popular within the area of IS to explore adoption within organizational arrangements resulting from the combination of work practices and features offered by innovative use of IT [9].

The concept originates from the argument that people pick up rich information relevant to their needs from objects within their environment, representing the affordances of the object, not the properties [12]. Affordances are neither properties of the environment nor the characteristics of the individual but are relative to the interaction between the actor and the artefact [13]. Affordance exists as a relationship between an actor and an artefact, being relative to the action capabilities of the actor and reflecting the possible actions on the artefact itself [14]. This relativity implies that affordances are specific to one actor; hence, an affordance for one actor may be com- 
pletely useless for another [12], who may not perceive or actualize the affordance. Affordances may be latent to begin with, needing to be perceived and actualized by a goal-oriented actor to achieve an outcome $[12,15]$.

The term was brought into IS to describe the action possibilities allowed by material properties within information systems [12], proposing a bridging concept to explain the intersection between IT systems and organizational systems [9]. This concept of affordances allows for the examination of how goal-oriented individuals interpret (and actualize) material properties within information systems to create changes in organizational practices [16]. As such, the concept of technological affordances relates not only to the individual level, but also to the action potential of what an organization can do with information systems with the intention to support organizational goals [14]. Organizational affordances relate to "the potential actions enabled associated with achieving organizational-level immediate concrete outcomes in support of organizational level goals" [17], resulting from the collective actions of the individuals.

Our motivation for introducing the concept of affordances here is to address our questions regarding how social media is being used (IT artefact), by whom (goal oriented actors), the consequences of the contextual factors (within a setting) and the consequences of this use (the resulting adoption). Our analyses are influenced by the work of Pozzi et al. [14], who proposes a theoretical framework (Figure 1) for affordances, which is introduced as a basis the empirical analyses here. In this study, we focus on affordances perception to some extent but mainly on affordance actualization and the effect of affordances in the context of ICT use, particularly social media, in promoting eParticipation. Pozzi et al. [14] found that there is a lack of research focused on those aspects of affordances.

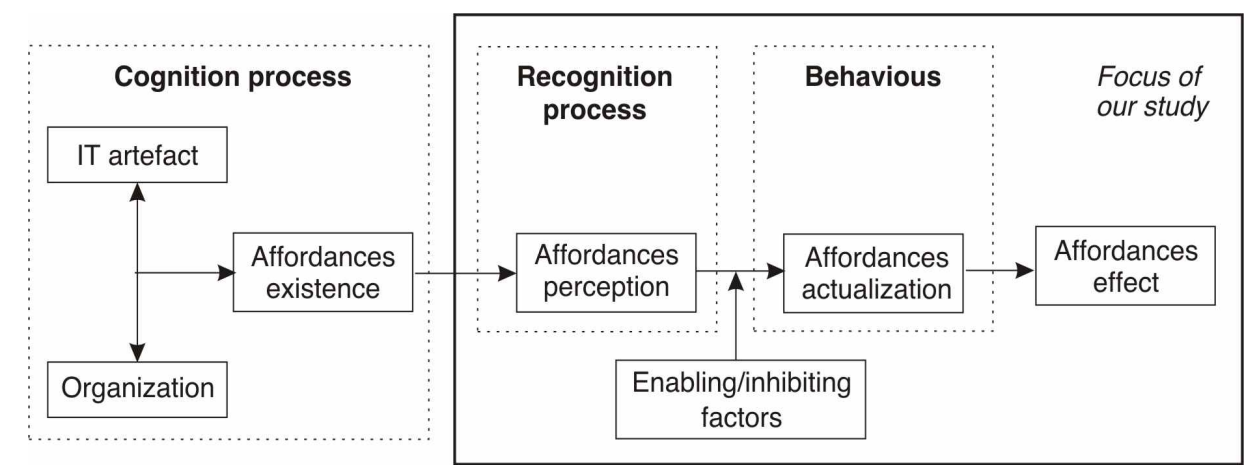

Fig. 1. Affordances theoretical framework inspired by Pozzi et al. [14]

\section{$3 \quad$ Research Context and Method}

Indonesia is among the top users of social media in the world. There are more than 70 million (out of around 250 million population) Facebook users and around 30 million Twitter users. The most active users of social media come from several big cities including Jakarta, which has the most active Twitter and Facebook users in the world, 
and Bandung. At the end of 2012, Bandung, the study site, had already the sixth most active Twitter users in the world ${ }^{1}$. Nowadays, WhatsApp - a cross-platform social media $^{2}$ - is also very popular ${ }^{3}$ as $57 \%$ of smart phone users in Indonesia are WhatsApp users ${ }^{4}$.

In this paper, we empirically analyse the Bandung case by adopting an interpretive approach with the aim of investigating and reflecting on the use social media to promote eParticipation within developing countries. Topics of interest include how and why social media is used, the impact of so doing and the enabling and inhibiting factors influencing such use, based on the concept of affordances.

We interviewed key actors and included online archival data in order to gain an understanding of the contextual conditions. Archival data included statistical material, reports from the projects and analyses of social media activities in Bandung, including more than 6,000 tweets posted by the mayor. Table 1 summarizes the distribution of the interviews in terms of roles.

\begin{tabular}{|l|c|}
\hline Role & Code of informant \\
\hline - Secretary of the Department for Communication and Informatics & B1 \\
\hline - Secretary of the Department for Education & B2 \\
\hline - Head of the Section for Public Services in a sub-district & B3 \\
\hline - Vice- head of a village & B4 \\
\hline - Head of Ombudsman & B5 \\
\hline - Head of the Section for Village Empowerment & B6 \\
\hline - Head of the Section for Sub-district Empowerment & B7 \\
\hline
\end{tabular}

Table 1. Distribution of interviews

The analysis began with the evidence emerging from the data, moving to a description of the structures and contexts. First, we used open coding to individually identify concepts. Second, the affordance perspective was introduced. Affordances produce immediate outcomes and events that were empirically observable; we looked for them in our empirical material by investigating our data sources to identify actual events, allowing us to identify the existence of affordances

\section{$4 \quad$ Findings and Analysis}

eParticipation services in Bandung have been highly influenced by the inauguration of a new mayor in September 2013. Unlike his predecessors, who came from bureaucratic circles, the new mayor has a professional background as an architect, a lecturer at a

\footnotetext{
${ }^{1}$ http://www.forbes.com/sites/victorlipman/2012/12/30/the-worlds-most-active-twitter-cityyou-wont-guess-it/

${ }_{2}^{2} \mathrm{http} / / / \mathrm{www}$.forbes.com/sites/benedictevans/2012/10/19/whatsapp-the-biggest-social-networkyouve-never-heard-of/

${ }^{3} \mathrm{http}: / /$ www.thejakartapost.com/news/2013/06/24/whatsapp-ri-strong-market-usagegrowth.html

${ }^{4}$ http://www.thejakartapost.com/news/2014/10/28/telkom-s-q3-earnings-lifted-internet-dataservices.html
} 
reputable national university, and a social activist. Soon after his inauguration, he asked all regional governmental agencies and their top management to establish email, Twitter, Facebook, and WhatsApp accounts. Some of them also established BlackBerry Messenger (BBM) access. The mayor himself is an active Twitter user, posting more than 6,000 tweets in his first 11 months of service.

Such use of ICT is part of a larger scheme to enhance the overall functioning of the city. According to one informant, "To provide public services, the government of Bandung attempts to utilise IT optimally" (B1). And indeed, under the new mayor's direction, these agencies have used e-mail, Twitter, and Facebook as channels to encourage public participation. Furthermore, their use of the WhatsApp application enables information sharing, visual reporting, and discussion and internal coordination-effectively allowing for the dynamic inclusion of relevant external actors such as representatives from the police department, the military, and youth organisations.

The function of Bandung's ICT-based eParticipation initiatives is, specifically, "to capture inputs and complaints from citizens directly. The mayor should be well informed about this, and the department should respond to these inputs and complaints directly" (B1). In October 2013, Bandung officially adopted LAPOR, a national complaint-handling system developed by the President's Delivery Unit for Development Monitoring and Oversight. The mechanism for processing the incoming messages is depicted in Figure 2. The system can be accessed through various channels, namely a website (i.e., www.lapor.ukp.go.id), social media sites and mobile applications (for Android, Blackberry, and IOS gadgets).

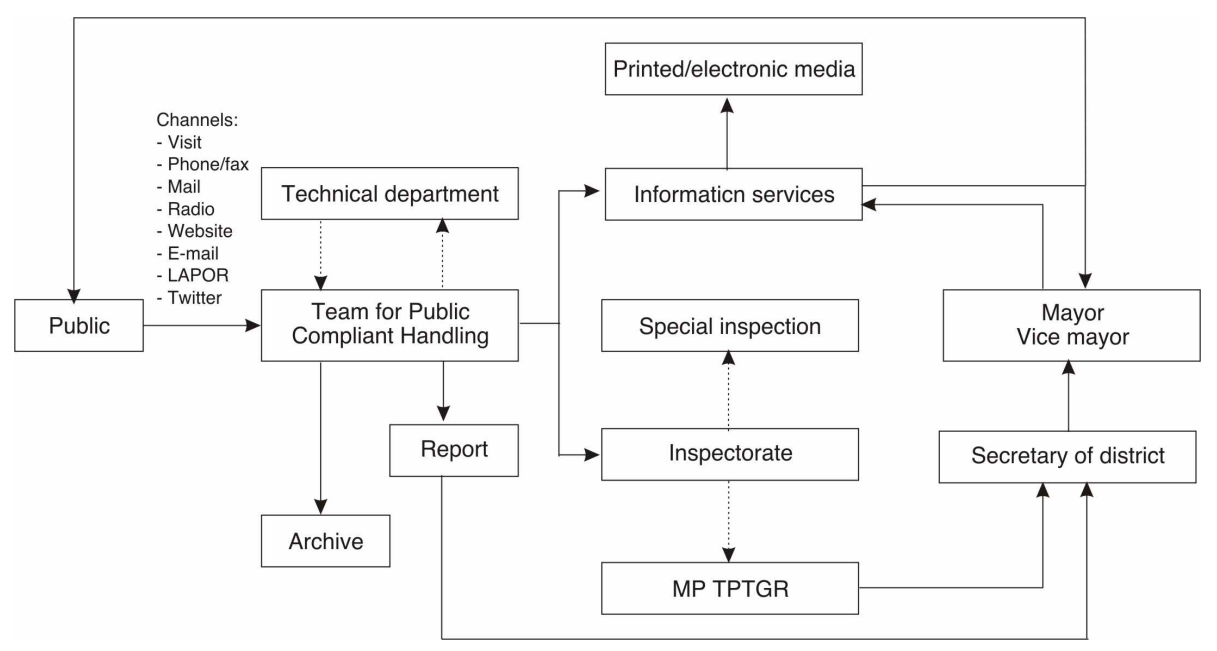

Fig. 2. Flow of incoming messages and responses in Bandung

Statistics from the first quarter of 2014 indicate that 2,723 incoming messages were recorded in LAPOR: $29 \%$ using the website and $71 \%$ using SMS. Of these 2,723 messages, $78 \%$ were appropriately responded to; the rest were archived for several reasons, such as they contained overly general suggestions, they were unclear 
in their meaning, or they were inappropriate (e.g., mocking). When the incoming messages deal with corruption practices the follow-up will involve inspectorate, special inspection, and Advisory Council for Compensatory Claim (Majelis Pertimbangan Tuntutan Perbendaharaan dan Ganti Rugi [MP TPTGR]). Figure 2 depicts the overview of the system used to encourage public participation, both with and without the help of ICT.

\subsection{Actualised affordances}

We identified nine actualised affordances emerged from the relation between Bandung's local government (Table 1). Some of these actualised affordances are directly related to the use of social media, such as facilitating direct communication and eliminating power distance; others are generated by other types of ICT use, such as supporting the internal business process and working ubiquitously.

\begin{tabular}{|c|c|}
\hline Actualised affordances & Excerpts \\
\hline $\begin{array}{l}\text { Facilitating direct } \\
\text { communication }\end{array}$ & $\begin{array}{l}\text { "All departments should have e-mail, Twitter, WhatsApp, and Facebook ac- } \\
\text { counts. Their function is to capture inputs and complaints from citizens direct- } \\
\text { ly." (B1) }\end{array}$ \\
\hline $\begin{array}{l}\text { Inviting citizen partici- } \\
\text { pation }\end{array}$ & $\begin{array}{l}\text { "I invited citizens [through Twitter] to participate in [the] trash picking move- } \\
\text { ment every Monday, Wednesday, and Friday. Now, Bandung is clean." (The } \\
\text { mayor of Bandung, quoted in [18]) }\end{array}$ \\
\hline Maintaining integrity & "So, there is no chance left to deceive, when we are using WhatsApp." (B1) \\
\hline $\begin{array}{l}\text { Eliminating power } \\
\text { distance }\end{array}$ & $\begin{array}{l}\text { I was aware, when I was elected as mayor, that social media would be an inte- } \\
\text { gral part of staying close to the citizens." (The mayor of Bandung, quoted in } \\
{[18] \text { ) }}\end{array}$ \\
\hline $\begin{array}{l}\text { Supporting the internal } \\
\text { business process }\end{array}$ & $\begin{array}{l}\text { "Each department should have at least five IS applications, to support the inter- } \\
\text { nal business process and to provide services to citizens." (B1) }\end{array}$ \\
\hline $\begin{array}{l}\text { Reporting activities } \\
\text { visually }\end{array}$ & $\begin{array}{l}\text { "When offices at all levels, until village, are performing an activity, they should } \\
\text { take a picture of it and post it through WhatsApp. All people [in the WhatsApp } \\
\text { group] will know about it, as well as the mayor." (B1) }\end{array}$ \\
\hline $\begin{array}{l}\text { Assessing officer per- } \\
\text { formance }\end{array}$ & $\begin{array}{l}\text { "[Social media activity] is used as one of the indicators in assessing the officers' } \\
\text { performance. When a head of a sub-district is working in the field, but she/he } \\
\text { does not report it, the mayor will not know it." (B1) }\end{array}$ \\
\hline $\begin{array}{l}\text { Facilitating internal } \\
\text { coordination }\end{array}$ & $\begin{array}{l}\text { "When we are going to hold a meeting, we inform [staff] about it through } \\
\text { WhatsApp... We still ... make a regular invitation letter [on] paper. We take a } \\
\text { photo of it and share it through WhatsApp." (B6) }\end{array}$ \\
\hline Speeding up processes & $\begin{array}{l}\text { "We send an activities report by e-mail to make sure it is quickly received, } \\
\text { especially by the current mayor. It was not so with the previous one." (B3) } \\
\text { "With eKelurahan }{ }^{5} \text { we can work more quickly." (B4) }\end{array}$ \\
\hline Working ubiquitously & $\begin{array}{l}\text { "As the data is stored in a server, we are not dependent on a specific computer." } \\
\text { (B4) } \\
\text { "The head of a sub-district may see the incoming letters through the system, and } \\
\text { make his disposition. ... I will get notification of that through SMS." (B3) }\end{array}$ \\
\hline
\end{tabular}

Table 2. Identified actualised affordances

5 eKelurahan is a web-based system developed to facilitate administration processes at the village level. It has been used in Bandung since December 2013. 


\subsection{Affordances effects}

Our data indicates that the actualised affordances identified above have resulted in six affordances effects (Table 2). Some of these effects, such as better public services and improved transparency, can be observed or experienced by citizens immediately. Other effects, such as improved institutional capacity and better working morale, are primarily experienced by the local government officers directly, though eventually they trickle down to impact citizens.

\begin{tabular}{|l|l|}
\hline $\begin{array}{l}\text { Affordances } \\
\text { effects }\end{array}$ & Description/excerpts \\
\hline $\begin{array}{l}\text { Improved citizen } \\
\text { participation }\end{array}$ & $\begin{array}{l}\text { This has been indicated by the significant number of incoming messages sent by } \\
\text { citizens in the form of complaints, questions, requests for information, suggestions, } \\
\text { etc. }\end{array}$ \\
\hline $\begin{array}{l}\text { Improved trans- } \\
\text { parency }\end{array}$ & $\begin{array}{l}\text { The use of Twitter made what the local government was doing transparent to the } \\
\text { public eye. In many cases, citizens demand information or clarification on certain } \\
\text { issues; thus, the local government should respond to it accordingly. }\end{array}$ \\
\hline $\begin{array}{l}\text { More responsive } \\
\text { government }\end{array}$ & $\begin{array}{l}\text { The mayor often mentions the Twitter account of relevant technical department to } \\
\text { follow up the reported issues/problems by citizens. In some cases, the mayor himself } \\
\text { make a field visit. } \\
\text { All technical departments should respond to incoming messages immediately, within } \\
\text { an agreed-upon timeframe. }\end{array}$ \\
\hline $\begin{array}{l}\text { Better public } \\
\text { services }\end{array}$ & $\begin{array}{l}\text { Feedback provided by citizens through the eParticipation systems (i.e., LAPOR) force } \\
\text { the local government to assure and improve the quality of public services. } \\
\text { "SIP6 is the mayor's idea to provide zero-complaint services." (B6) } \\
\text { "[The] ombudsman changed the status of 18 technical departments from yellow to } \\
\text { green7." (B1) }\end{array}$ \\
\hline $\begin{array}{l}\text { Improved institu- } \\
\text { tional capacity }\end{array}$ & $\begin{array}{l}\text { "[Information systems are developed] to improve institutional capacity, both at the } \\
\text { sub-district and the village level, which essentially [offers] better public services." } \\
\text { (B6) }\end{array}$ \\
\hline morale & $\begin{array}{l}\text { "In some cases, the officers are not ready yet when they are 'attacked' on Twitter or } \\
\text { Facebook. They have no choice. The have to have resilience [...] to work properly." } \\
\text { (B1) }\end{array}$ \\
\hline
\end{tabular}

Table 3. Identified affordances effects

\subsection{Enabling and inhibiting factors}

Seven enabling and inhibiting factors where identified, in terms of converting the possibility of action (i.e., affordances perception) into actual action (i.e., affordances actualisation) (see Table 4). These factors can be grouped into four categories: (i) top

${ }^{6}$ SIP (i.e., www.sip.bandung.go.id) is a web-based system that enables citizens to assess the quality of the public services they experience from a specific government office.

${ }^{7}$ Green status is the highest status level, indicating that the technical department meets the minimum standard of public service. Yellow status is the intermediate status level, indicating that the technical department does not yet meet the minimum standard of public service. 
management (political goodwill, focus shifting, reward systems); (ii) government officers (technical skill and knowledge readiness, transparency culture); (iii) external actors (supports from the local parliament); and (iv) citizens (social media use among citizens).

\begin{tabular}{|c|c|}
\hline $\begin{array}{l}\text { Affordances } \\
\text { effects }\end{array}$ & Excerpts \\
\hline Political goodwill & $\begin{array}{l}\text { "This initiative can be copied by other local governments. All is dependent on the } \\
\text { goodwill of the top management." (B1) } \\
\text { "In coping with tweets containing criticism, mockery, and intimidation, my patience } \\
\text { already reaches to the God level." (The mayor of Bandung, quoted in [19]. }\end{array}$ \\
\hline $\begin{array}{l}\text { Technical skill } \\
\text { and knowledge } \\
\text { readiness }\end{array}$ & $\begin{array}{l}\text { "Fortunately, our operator has ... good skill in computer and Internet, and she gradu- } \\
\text { ated from communication studies, so we have no significant burden. ... But, [at the } \\
\text { beginning,] the dubiety of the operators in answering the incoming messages could be } \\
\text { a challenge. We classified the messages, which ones ... can be answered by her di- } \\
\text { rectly, which ones ... need to be filtered, and which ones need to be consulted about } \\
\text { with the top management." (B2) } \\
\text { "The basic IT skill of the officers [at] the village level is inadequate. ... We gave them } \\
\text { technical assistance in collaboration with the developer of the system. We also re- } \\
\text { cruited skilled officers." (B7) }\end{array}$ \\
\hline Focus shifting & $\begin{array}{l}\text { "Our department's focus was on managing public relations, as a government repre- } \\
\text { sentative to balance the media reporting. ... Nowadays, we are responsible [for devel- } \\
\text { oping] IT-based service. Each department should have at least five IS applications, to } \\
\text { support the internal business process and to provide services to citizens." (B1) }\end{array}$ \\
\hline Reward systems & $\begin{array}{l}\text { "[Social media activity] is used as one of the indicators in assessing the officers' } \\
\text { performance. ... We rank the performance of the heads of the sub-districts. The best } \\
\text { ten have been sent to South Korea for a comparative study." (B1) }\end{array}$ \\
\hline $\begin{array}{l}\text { Social media use } \\
\text { among citizens }\end{array}$ & $\begin{array}{l}\text { "A study conducted in Bandung, inhabited by } 2.5 \text { million people, found that most } \\
\text { citizens have a social media account, including students of junior and senior high } \\
\text { schools. Another study told us, in accessing information, that television is the first } \\
\text { source [for information], and the second one is social media." (B1) }\end{array}$ \\
\hline $\begin{array}{l}\text { Supports from } \\
\text { the local parlia- } \\
\text { ment }\end{array}$ & $\begin{array}{l}\text { "At the beginning, the benefits of using such a system were unclear. ... The nature of } \\
\text { budget allocation for developing IS applications is abstract. It can be either cheap or } \\
\text { expensive. They [the local parliament] were in doubt. ... But, finally our proposal was] } \\
\text { granted." (B3) }\end{array}$ \\
\hline $\begin{array}{l}\text { Transparency } \\
\text { culture }\end{array}$ & $\begin{array}{l}\text { "[In the beginning], their acceptance varied, since they were not used to being trans- } \\
\text { parent, but now they have to. Citizens can give corrections and input." (B1) }\end{array}$ \\
\hline
\end{tabular}

Table 4. Identified enabling and inhibiting factors

The connection between affordances perception, affordances actualisation, and affordances effect, along with the associated enabling/inhibiting factors, is depicted in Figure 3.

\section{Discussion}

When studying affordances, it is necessary to understand the motivation in which the actor's goals are embedded. Motivation is particularly important to the current case study as it influences affordances perception [14]. Affordances perception yields awareness of the possibilities of action [20]. It is about recognising the possibilities 
brought about by the technology in question - in this case, ICT. Indeed, in our case study, we found that the mayor of Bandung was very aware of the potential for social media to promote citizen participation:

I see it from a different perspective. Social media is not my personal domain. I consider it as part of work. When I respond to a tweet, I am working. A lot of benefits can be harvested from using social media. Bandung has become clean because of social media. (The mayor of Bandung, quoted in [18]).

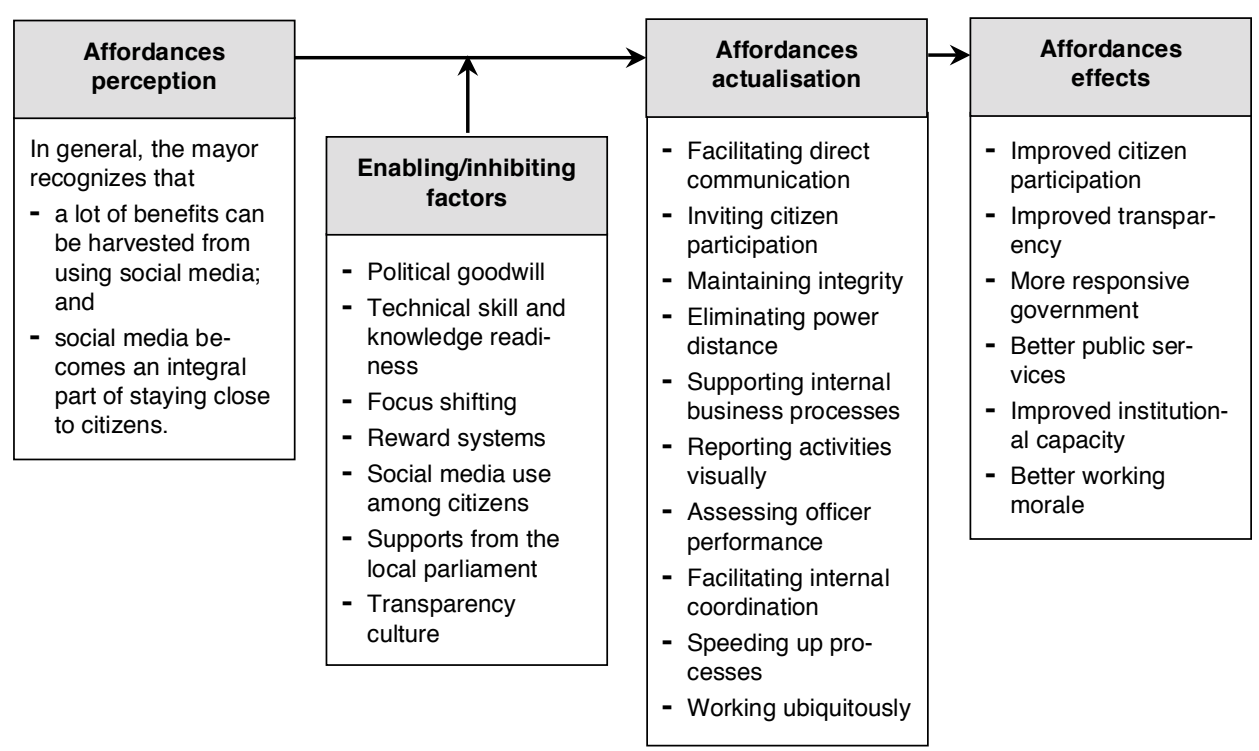

Fig. 3. The connection between affordances perception, affordances actualisation, and affordances effect, and its relation to associated enabling/inhibiting factors

Affordances perception can be viewed as inductive thinking [21]. In contrast to deductive thinking, inductive thinking can lead to more disruptive and innovative uses of technology, as asserted by [21] ( pp. 84-85):

Most executives and managers know how to think deductively. That is, they are good at defining [a] problem or problems, then seeking and evaluating different solutions to it. But, applying information technology to business reengineering demands inductive thinking - the ability to first recognize a powerful solution and then seek the problems it might solve, problems the company probably doesn't even know that it has.

Affordances perception influences affordances actualisation [14]. For example, all of the affordances presented in Figure 3 have been actualised in the case of Bandung, exemplified by the official use of social media such as Twitter, and WhatsApp. As one informant asserted of Bandung's local government, "[To obtain feedback] our Twitter is the most active [channel used by citizens]" (B2). 
The connection between affordances perception and affordances actualisation has emerged from the empirical evidence on whether the enabling/inhibiting factors impact whether or not officials are able to act in relation to their goals. Our analyses explored both the positive and the negative influences on affordances actualisation. Though the concept of affordances is usually discussed from the positive perspective $[9,16,22]$, affordances are defined in the literature as a dual concept [23, 24], emphasising that technology can both enable and constrain.

Our data indicates that affordances perception may play a very general role in identifying the action possibilities provided by certain technologies (such as social media) when they interact with specific contexts (e.g., eParticipation). However, in practice, this may lead to the emergence of unanticipated affordances actualisation. For example, at the beginning of a eParticipation initiative, it might be difficult to imagine how the use of social media could eliminate power distance; however, it does - and it is realised only after the affordances have been actualised. We could relate this to the concept of 'bounded rationality,' which holds that decision making is often conducted based on limited information [25]. Even more, some affordances actualisation may emerge to respond to new possibilities, as noted by [14]; indeed, the actualisation of an affordance may result in enabling conditions for additional affordances. For example, affordances facilitating internal coordination and enabling working ubiquitously may lead to another affordance (e.g., speeding up processes). This finding leads to a discussion regarding how useful it actually is to make a plan (e.g., a plan to use social media to increase citizen participation), especially in the context of developing countries. Likely, in such cases, a general plan would still be needed-but not necessarily an exhaustive one.

\section{Conclusion}

In this paper, we have employed a case study approach to identify instances of affordance perception, affordance actualisation, and affordance effects, as well as a number of influential enabling and inhibiting factors. By so doing, we have contributed to the area of eParticipation by demonstrating how the concept of affordances helps to make sense of the consequences of introducing ICT for the sole purpose of citizen participation. We have shown this by analysing the interactions between a goal-oriented actor (i.e., the new mayor of Bandung), the ICT artefacts, and the surrounding environment. Our contribution includes identifying nine actualised affordances, isolating the link between these nine affordances and certain affordances effects, and exploring the relationship between affordances perception and affordances actualisation (as enabled or inhibited by various identified contextual factors).

The case findings introduced here is based on empirical evidence collected at a single point in time, without access to longitudinal data. The concept of affordances (with a particular focus on action possibilities and the relationship between perception, actualisation, and effects) allows for further investigation into cause and effect by exploring how actions lead to the actualisation of affordances. Future research is 
needed to further our understanding of causal effects, particularly in terms of exploring longitudinal data from Bandung.

Practical implications of our work include disseminating the lessons learned from the success story of Bandung, where the introduction of LAPOR has boosted civic participation from citizens and other public stakeholders. Practitioners could learn from these experiences by, for instance, exploring how the various factors influence affordance effects. Such an inquiry would lead to increased understanding of how perceptions and enabling/inhibiting factors influence affordances actualisation and effects - the main objectives for any eParticipation initiative. Another important lesson that can be taken from the Bandung case is related to disruption and the disruptive perspective [8], which helps us to understand how ICT innovations can exhibit fundamental discontinuity. More research is needed before we can fully understand how disruptive moments can influence the success of eParticipation initiatives.

Our findings provide ample avenues for future research. First, the nature of our identified affordances and the relationship between them should be further investigated to enhance our understanding of collective actions within eParticipation projects. Questions to be answered include what motivates people to join and how knowledgesharing processes take place within eParticipation projects [26]. Secondly, affordances have a relative nature [14], which implies that affordances actualised by some individuals might be of no use to other individuals. Hence, our contributions provide a starting point for research within different empirical settings. For instance, researchers could extend our theoretical approach by identifying different affordances, different relationships between the concepts, and different interaction patterns. Our findings could also be introduced to confront different eParticipation projects through comparative studies.

\section{References}

1. Medaglia R (2012) eParticipation research: Moving characterization forward (2006-2011). Gov Inf Q 29:346-360. doi: 10.1016/j.giq.2012.02.010

2. Rahman MM, Ahsan Rajoin SA (2012) An Effective Framework for Implementing Electronic Governance in Dveloping Countries: Bangladesh Perspective. Int J Comput Inf Technol 3:360-365.

3. Veit D, Huntgerburth J (2014) Foundations of Digital Government. Leading and Managing in the Digital Era. 158. doi: 10.1007/978-3-642-38511-7_9

4. Criado JI, Sandoval-Almazan R, Gil-Garcia JR (2013) Government innovation through social media. Gov Inf Q 30:319-326. doi: http://dx.doi.org/10.1016/j.giq.2013.10.003

5. Van Dijk J (2000) Models of democracy and concepts of communication. Digit. Democr. Issues Theory Pract.

6. Kavanaugh AL, Fox E a., Sheetz SD, et al. (2012) Social media use by government: From the routine to the critical. Gov Inf Q 29:480-491. doi: 10.1016/j.giq.2012.06.002

7. Borins S (2005) A Holistic View of Public Sector Information Technology. J E-Government 1:3-29. doi: 10.1300/J399v01n02_02

8. Lyytinen K, Rose GM (2003) Disruptive information system innovation: The case of internet computing. Inf Syst J 13:301-330. doi: 10.1046/j.1365-2575.2003.00155.x 
9. Zammuto RF, Griffith TL, Majchrzak A, et al. (2007) Information Technology and the Changing Fabric of Organization. Organ Sci 18:749-762. doi: 10.1287/orsc.1070.0307

10. Gibson JJ (1986) Gibson Theory of Affordances.pdf. Chapter Eight The Theory of Affordances 127-136.

11. Gibson JJ (1977) A Theory of Affordances. Perceiving, Act. Knoweing Towar. an Ecol. Psychol., R. Shaw, J. Lawrence Erlbaum Associates, Hillsdale, NJ, pp 67-82

12. Markus ML, Silver MS (2008) A Foundation for the Study of IT Effects: A New Look at DeSanctis and Poole's Concepts of Structural Features and Spirit *. J Assoc Inf Syst 9:609632. doi: Article

13. Chemero A (2003) An Outline of a Theory of Affordances. Ecol Psychol 15:181-195. doi: $10.1207 / \mathrm{S} 15326969 \mathrm{ECO} 1502 \_5$

14. Pozzi G, Pigni F, Vitari C (2014) Affordance Theory in the IS Discipline: a Review and Synthesis of the Literature.

15. Bernhard E, Recker J, Burton-Jones A (2013) Understanding the Actualization of Affordances: A Study in the Process Modeling Context. ICIS 2013 Proc.

16. Seidel S, Recker J, Vom Brocke J (2013) Sensemaking and sustainable practicing: Functional affordances of Information Systemts in Green Transformation. MIS Q 37:12751299.

17. Strong DM, Johnson SA, Tulu B, et al. (2014) A Theory of Organization-EHR Affordance Actualization. J Assoc Inf Syst 15:53-85.

18. Derby D (2014) Ini trik Walikota Bandung agar dekat dengan rakyat. Tangerangnews.com

19. Yudiman M, Sufyan M (2014) Twitter Power@Ridwankamil. Publika Edu Media

20. Michaels CF (2003) Affordances: Four points of debate. Ecol Psychol 15:135-148.

21. Hammer M, Champy J (1993) Reengineering the corporation: a manifesto for business reengineering. Nicholas Brealey Publ. London

22. North-Samardzich A, Braccini AM, Spagnoletti P, Za S (2014) Applying Media Synchronicity Theory to Distance Learning in Virtual Worlds: a Design Science Approach. Int J Innov Learn 15:328-346.

23. Hutchby I (2001) Technologies, Texts and Affordances. Sociology 35:441-456.

24. Volkoff O, Strong DM (2013) Critical Realism and Affordances: Theorizing IT-Associated Organizational Change Processes. MIS Q 37:819-834.

25. Simon HA (1991) Bounded Rationality and Organizational Learning. Organ Sci 2:125-134. doi: 10.1287 /orsc. 2.1 .125

26. Federici T, Braccini AM, Sæbø Ø (2015) “Gentlemen, all aboard!” Using ICT to directly involve citizens in party politics. Lessons learned from the Italian Five Stars Movement, Government Information Quarterly. 